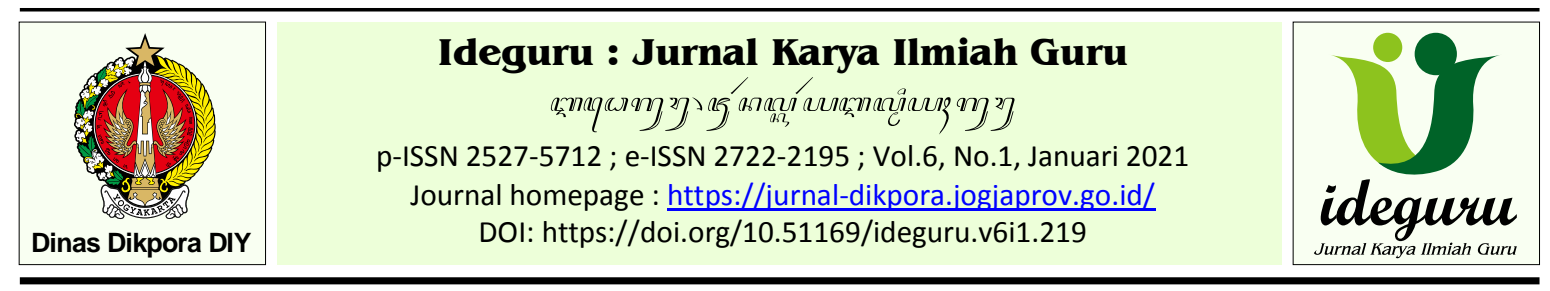

Best Practice - Naskah dikirim: 31/01/2021 - Selesai revisi: 09/03/2021 - Disetujui: 11/03/2021 - Diterbitkan: 15/03/2021

\title{
Peranan Siniar sebagai Media Pembelajaran Sosiologi di Masa Pandemi
}

\author{
Martini Sugatri \\ SMA Negeri 1 Bantul \\ martinisugatri79@gmail.com
}

\begin{abstract}
Abstrak: Tujuan penelitian ini adalah untuk mengetahui peranan Siniar sebagai media pembelajaran sosiologi dalam pembelajaran jarak jauh di masa pandemi di Kelas XII IPS2 di SMAN 1 Bantul Semester 2 tahun Pelajaran 2020/2021. Penulisan best pratice ini termasuk jenis penelitian dengan pendekatan kualitatif deskriptif. Penulis menggambarkan pengalaman terbaiknya dalam memecahkan permasalahan yang dihadapi dalam proses pembelajaran jarak jauh di masa pandemi covid-19. Subjek penelitian ini adalah siswa kelas XII IPS2 SMAN 1 Bantul Semester 2 tahun pelajaran 2020/2021 dan lokasi peneletian ini adalah SMAN 1 Bantul. Subyek dalam penulisan ini sebanyak 32 responden. Data yang digunakan adalah data primer yang didapat dengan menggunakan google form. Teknik pengumpulan data yang dilakukan dengan membagikan kuesioner. Teknik analisis data yang digunakan dalam analisis ini mengunakan pengumpulan data melalui google form. Tahap yang dilakukan yaitu mereduksi data yang ada yang ada dalam google form, tahap menyajikan data dalam bentuk data kualitatif dan data kuantitatif dan terakhir tahap membuat penarikan kesimpulan. Hasil penelitian dari penggunan Siniar sebagai media pembelajaran sosiologi di masa pandemi adalah bahwa sebanyak 100\% responden menyatakan menyukai penggunaan Siniar, 92,3\% responden menyatakan paham terhadap materi yang digunakan dan 100\% responden menyatakan mudah dalam penggunaan Siniar sebagai media pembelajaran. Selain itu bahwa penggunaan Siniar dapat meningkatnya minat dan motivasi belajar siswa dalam mengikuti proses pembelajaran selama masa pandemi. Penggunaan Siniar ini merupakan salah satu solusi dalam pembelajaran jarak jauh di masa pandemi covid-19.
\end{abstract}

Kata Kunci: Siniar, pembelajaran jarak Jauh, media pembelajaran, pandemi, sosiologi

\section{The role of Podcast as a Learning Media of Sociology in Pandemic Era}

Abstract: The purpose of this research is to know the role of podcast as a media to learn sociology in distance learning in pandemic era at class XII IPS2 SMAN 1 Bantul semester 2 in academic year 2020/2021. The writing of this best practice belongs to a research which uses descriptive qualitative approach. The writer describes her best experience in solving the problem faced in the distance learning process in pandemic era of covid-19. The subject of the research is the students of class XII IPS 2 in SMAN 1 Bantul in second semester in academic year 2020/2021 and the location of the research is SMAN 1 Bantul. The subject or the research consisits of 32 respondents. The data which are used are primary data taken by using google form. The data were collected through questionnaire. The data were analyzed by using data collection through google form. The steps which were used consisted of reducing the data available in google form, presenting the data in qualitative data and quantitative form, and drawing a conclusion. The result of the research of using of podcast as a media to learn sociology in pandemic era is $100 \%$ of the respondents state that they like using podcast, 92,3\% of the respondents state that they understand the material given through podcast, and 100\% of the respondents state that podcast is easy to use as a media of learning. Besides, using podcast improves students' interest and motivation to study in pandemic era. Using this Podcast is one of the solutions in distance learning in pandemic era of covid-19. Keywords: Podcast, distance learning, learning media, pandemic, sociology

\section{Pendahuluan}

Hampir selama satu tahun penyebaran covid-19 telah melanda di semua daerah di Indonesia. Daerah-daerah yang dulunya dalam tingat kerawanan penyebaran covid-19 kategori daerah orange sudah berubah menjadi kategori daerah merah. Penyebaran covid-19 telah dalam tingkat resiko yang tinggi di Indonesia. Di Pulau Jawa dan Bali mulai dilaksanakan Pemberlakuan Pembatasan Kegiatan Masyarakat atau PPKM pada tanggal 11 Januari 2021 berdasarkan Surat Instruksi Menteri Dalam Negeri Republik Indonesia Nomor 01 Tahun 2021 tanggal 6 Januari 2021. 
Beberapa struktur sosial kehidupan masyarakat telah mengalami perubahan akibat pandemi covid-19. Struktur sosial yang ada dalam masyarakat harus dapat menyesuaikan terhadap perubahan sosial yang terjadi saat ini agar dapat bertahan terhadap situasi pandemi covid-19.

Perubahan pada struktur sosial dalam masyarakat berdampak besar dalam kehidupan masyarakat saat ini. Salah satunya strukstur sosial yang bertranformasi adalah dalam lembaga pendidikan. Lembaga pendidikan melakukan dengan pembelajaran jarak jauh dalam jaringan. Pembelajaran jarak jauh dengan dalam jaringan ini telah mengubah pendidikan yang dulunya bersifat konservatif. Pendidikan harus melakukan pembiasaan baru terhadap keadaan ini.

Pembiasaan baru yang harus dilakukan oleh semua elemen pendidikan dari mulai kegiatan belajar mengajar, pemberian soal ujian, melaksanakan program sekolah (rapat, kegiatan OSIS) dan sebagainya harus secara daring (dalam jaringan) untuk mencegah penyebaran covid-19. Dibutuhkan motivasi, dorongan psikologis serta sosialisasi yang bagus terhadap semua elemen stakeholder pendidikan untuk dapat menyesuaikan dirinya dengan kebiasaan baru atau "new normal" dalam pendidikan.

Dalam menghadapi kebiasaan-kebiasaan baru dalam pembelajaran tersedia berbagai pembelajaran digital dan media pembelajaran secara online. Beberapa platfom digunakan oleh masyarakat khususnya para pendidik. Dimulai dari video conference aplikasi zoom cloud meeting, cisco webec meeting, skype, dan google meet dan sebagainya. Untuk yang berupa e-learning dalam Learning Manajemen Sistem ada yang berupa google classroom, microsoft teams, edmodo, ruang guru. Penggunaaan media sosial yang berupa whatsApp, telegram, line, dan Siniar dijadikan sebagai media pembelajaran.

Penggunaan dari berbagai aplikasi tersebut menyebabkan munculnya berbagai permasalahan dan polemik dalam dunia pendidikan. Sebagai contoh dalam penggunaan video conference berupa penggunaan zoom cloud meeting untuk melakukan pembelajaran tatap muka banyak dikeluhkan karena sinyal yang tidak dapat ditangkap oleh handphone siswa, kurang pahamnya penggunaan aplikasi, memakan kuota internet, kuota limit, siswa yang tidak dapat mengikuti video conference karena ketiduran dan sebagainya.

Permasalah tersebut akan menyebabkan motivasi belajar menjadi rendah karena fasilitas dan letak geografis yang digunakan oleh para siswa berbeda. Ada siswa yang berada di daerah blank hotspot (daerah tidak ada jaringan internet) dan ada siswa yang berda di daerah perkotaan. Karakteristik siswa juga ada siswa yang berasal dari keluarga tidak mampu, sedang dan mampu dalam mengakses pendidikan secara daring ini. Untuk siswa yang berasal dalam blank hotspot (tidak ada jaringan internet) dan siswa yang tidak mampu membeli kuota akan kesulitan untuk mencari jaringan apabila menggunakan video conference sedangkan siswa yang di daerah perkotaan dan siswa yang mampu akan mudah mengakses pembelajaran yang dilakukan oleh guru. Disinilah terjadi gap peserta didik untuk mengakses pendidikan di masa pandemi.

Permasalahan yang lain adalah untuk penggunaan video conference adalah guru kadang hanya memberikan ceramah dalam pembelajaran, siswa harus mematikan microphone-nya yang menyebabkan siswa tidak aktif, etika siswa dalam mengikuti kegiatan pembelajaran misalnya masuk ke room meeting setelah 30 menit pembelajaran berlangsung, pematikan kamera kemudian siswa ditinggal main game atau tidur. Hal ini menyebabkan transformasi pendidikan tidak bisa berjalan dengan baik.

UNICEF menyampaikan bahwa anak menjadi tidak nyaman belajar dari rumah sebesar 66\%. Alasannya bahwa kurangnya bimbingan dari guru sebesar 38\% dan akses internet yang buruk dalam pembelajaran jarak jauh. Apabila pembelajaran jarak jauh tetap berlanjut maka ada sekitar $62 \%$ siswa membutuhkan internet. (UNICEF, 2020)

Dari berbagai permasalahan yang ditimbulkan dalam pembelajaran jarak jauh ini menjadi tantangan tersendiri oleh penulis untuk memecahkan permasalah tersebut. Kurang optimalnya pembelajaran dengan berbagai platform video conference yang tidak memihak siswa dalam mengakses pendidikan secara adil bagi seluruh siswa dan efisiensi waktu yang tidak bisa optimal menyebabkan penulis harus membuat suatu strategi pembelajaran bagi semua siswa khususnya mata pelajaran sosiologi.

Pembelajaran sosiologi yang merupakan salah satu mata pelajaran dalam ilmu pengetahuan sosial juga mempunyai permasalahan. Masalahnya materi yang ada dalam mata pelajaran bersifat teoritis dan membosankan bagi siswa apabila guru tidak dapat mengemasnya menjadi menarik. Pada waktu dilakukan video conference guru kadang hanya menyampaikan dalam bentuk power point dan siswa akan menjadi jenuh mendengarkannya karena secara psikologis, siswa takut kuotanya akan semakin habis. 
Berdasarkan permasalahan di atas maka penulis mempelajari bahwa ada peluang dan potensi yang dapat dimanfaatkan dengan baik adalah dengan penggunaan Siniar. Penggunaan Siniar ini sebagai solusi untuk menjawab persoalan di atas terkait pembelajaran jarak jauh yang dapat diakses oleh semua siswa dan irit biaya. Siniar adalah salah satu media pembelajarn yang mengggunakan siaran audio yang dapat ditanyangkan secara streaming. Semua siswa dapat mendengarkan kapan saja dan dimana saja sehingga pembelajaran dalam penyampaian materi dapat diakses dengan mudah.

Oleh karena itu maka perumusan masalah dalam penulisan best practice ini adalah bagaimana peranan Siniar sebagai media pembelajaran sosiologi dalam pembelajaran jarak jauh di masa pandemi di siswa kelas XII IPS2 SMAN 1 Bantul Semester 2 Tahun Pelajaran 2020/2021.

Tujuan Penulisan best practice ini adalah untuk mengetahui bagaimana peranan Siniar sebagai media pembelajaran sosiologi di masa pandemi di Kelas XII IPS2 SMAN 1 Bantul Semester 2 Tahun Pelajaran 2020/2021. Manfaat dalam penulisan best practice adalah bagi siswa bahwa dengan pengunaan Siniar sebagai media pembelajaran sosiologi dalam pembelajaran jarak jauh maka materi yang diberikan akan mudah diakses. Bagi guru bahwa peranan Siniar sebagai salah satu pilihan penggunaan media pembelajaran pembelajaran jarak jauh. Bagi sekolah menumbuhkan kreatifitas dan pengetahuan yang baru dalam pengajaran dan menciptakan iklim yang baik untuk meningkatkan kompetensi mengajar di sekolah. Dan bagi orang tua dan masyarakat bahwa dengan peranan Siniar sebagai media pembelajaran dapat menumbuhkan kepercayaan orang tua dan masayarakat terhadap pihak sekolah sebagai solusi dalam melaksanakan kegiatan pembelajaran jarak jauh di masa pandemi covid-19.

\section{Tinjauan Pustaka \\ Media Pembelajaran Jarak jauh}

Guru dan teknologi berperan penting untuk mengukur pelaksanaan dalam pembelajaran jarak jauh. Guru harus mampu mengunakan teknologi agar pembelajarannya menyenangkan bagi siswa. Untuk itu seorang pendidik harus melakukan pemilihan media pembelajaran yang tepat agar siswa dapat mengikuti pembelajaran yang berlangsung dengan senang di masa pandemi ini.

Teknologi memainkan peran penting dalam pendidikan. Peran penting teknologi adalah dalam menghadapi pendidikan siswa yang mempunyai ciri kekhususan. Secara khusus bahwa teknologi dan media yang digunakan dapat memberikan masukan bagi pembelajaran yang efektif bagi semua siswa. Hal ini akan membantu siswa untuk mencapai hasil belajar tertinggi terlepas dari kemampuan bawaan mereka. (Sharon E Smaldino, Deborah L Lowther dan James D Russell, 2014). Menurut Bullen bahwa pembelajaran e-learning sebagai pembelajaran jarak jauh yang menggunakan teknologi internet untuk memberikan fasilitas dalam menyampaikan pesan selama proses kegiatan pembelajaran jarak jauh dilaksanakan. (P.Janes, Mark Bullen \& Diane, 2007)

Dalam menentukan media pembelajaran, pemilihan strategi mengajar guru pada saat terjadi pandemi akan menentukan tingkat keberhasilan pembelajaran. Data yang cukup memberikan saran kepada guru untuk menentukan cara memberikan pengalaman kepada pelajar sehingga mereka perlu membangun pemahaman mereka tentang dunia di sekitar mereka. Guru berencana untuk mengatur lingkungan belajar untuk memastikan bahwa siswa merasa tertantang dan siap secara emosional untuk menerima materi guru.

Media adalah segala sesuatu yang digunakan untuk merangsang pikiran dan menimbulkan kesan dalam menumbuhkan semangat, perhatian serta kemauan siswa dalam mendorong proses kegiatan belajarnya. Media juga dapat mengembangkan kepribadian siswa agar berkembang dengan baik. (Kosasi, Robertus Angkowo \& A., 2007)

Menurut Wilkinson bahwa pemilihan media harus memperhatikan juga beberapa hal yaitu tujuan yang akan dirumuskan, ketepatan penggunaan bahan yang menghasilkan dan meningkatkan hasil belajar, keadaan siswa yang tidak tergantung antar individu, ketersediaan untuk digunakan dalam mencapai tujuan pembelajaran. (Kosasi, Robertus Angkowo \& A., 2007)

Karakteritik media pembelajaran mempunyai perbedaan dalam pemakainnya yang harus dipahami oleh semua pemakainya. Dalam menentukan pemilihan media maka yang perlu dipertimbangkan adalah jenis media dan karakteristik siswanya. Perlu diperhatikan beberapa pertimbangan dalam pemilihan media ini adalah kejelasan tujuan dan maksud dalam pemilihan media, ciri dan sifat media yang akan digunakan, melakukan pembanding dengan media yang lain. Pemilihan pembanding dengan media yang lain dilakukan karena pemilihan media menjadi keputusan seorang guru untuk 
menentukan pengambilan keputusan dalam pembelajaran yang akan dilakukan terhadap alternatif-alternatif pertimbangan pemilihan media yang lain

Media pembelajaran merupakan stimulasi fisik berupa film, foto, rekaman suara, hingga mengkomunikasikan isi pesan kepada siswa. (Bringgs, 1977). Ada berbagai jenis media pembelajaran diantaranya media virtual (gambar grafik, diagram tabel, chat, bagan, poster, kantun, komik, infografis), media audio (Siniar, radio, tape recorder, laboratoriun bahasa Inggris/ Indonesia/ asing), Projected still media (slide, over head projector), dan rojected motion media (film-film menggunakan you tube, video pembelajaran guru maupun animasi)

Sedangkan untuk fungsi media pembelajaran adalah memberikan kesempatan untuk mencapai materi yang lebih, keefektikan proses pembelajaran yang dilakukan oleh guru, sebagai alat komunikasi siswa dan guru selama proses pembelajaran, memberikan contoh yang konkret kepada siswa (Schramm, 1977)

Dengan pemilihan media pembelajaran, kegiatan pembelajaran akan dapat membangkitkan keinginan belajar dan memberikan rangsangan belajar serta memberikan pengaruh psikologi terhadap siswa yang akan memberikan hasil yang optimal. Menurut Martin bahwa motivasi adalah suatu energi yang ada dalam siswa yang dapat mengarahkan, mengelompokkan, dan menimbulkan tingkah lakunya dalam pembelajaran. Motivasi menjadi komponen utama dalam pembelajaran yang sulit diukur. (Handoko, 2002)

Penelitian yan relevan dengan penulisan best practice ini yaitu oleh Faiza dengan judul "Podcast sebagai Sumber Belajar Berbasis Audio". Hasil analisisnya menggambarkan dalam studinya bahwa penggunaan Siniar dapat melampaui batas ruang dan waktu. Dibandingkan media audio lain, nilai terobosan Siniar ini adalah dapat diunduh dan disimpan di laptop dan perangkat seluler. Keunggulannya bisa digunakan di mana saja dan kapan saja untuk memastikan Siniar sangat sukses dan andal. Dengan demikian, siswa dapat melakukan hal-hal lain, seperti berbaring, memasak, atau mengemudi. (Faiza Indriastuti \& Wawan Tri Saksono TEst, 2014)

Penggunaan Siniar juga dapat digunakan oleh siswa untuk memahami prinsip, ide dalam implementasi pembelajaran jarak jauh.(Ratna Dwi Susilowati,Sutama Sutama, Nuqhty Faiziyah, 2020). Siniar ini juga bisa diperluas ke topik sejarah dalam ilmu sosial yang berhasil meningkatkan pembelajaran sebesar 45,9 persen dan dengan menggunakan media audio berbasis Siniar pada konten Sriwijaya dalam kategori yang tinggi. (Adhitya Rol Asmi, Aulia Novemy Dhita, Supriyanto, 2019)

Dari berbagai permasalahan dan kajian diatas maka dalam penulisan best practise ini penulis menggunakan media Siniar dalam pembelajaran daring di masa pandemi untuk mata pelajaran sosiologi. Pemilihan media ini dengan berbagai pertimbangan oleh penulis yang diharapkan dapat menjadi solusi pembelajaran daring di masa pandemi ini untuk menumbuhkan semangat belajar.

\section{Penggunaan Siniar}

Siniar sebagai platform pembelajaran yang memanfaatkan teknologi untuk menjawab tantangan selama pembelajaran jarak jauh di masa pandemi. Dalam pembelajaran, setiap guru dapat menggunakan Siniar ini untuk memanfaatkannya. Siniar yang bisa diakses di mana saja, menurut Komppelman, bisa memudahkan dalam belajar jarak jauh. (Komppelman, 2013)

Siniar ini berbeda dengan siaran radio yang sering kita dengar jaman dahulu. Radio memiliki jadwal siaran yang terstruktural dan memiliki materi yang khusus di setiap waktu pemutarannya. Untuk radio tidak menggunakan internet dalam mengaksesnya. Sedangkan Siniar menggunakan jaringan internet dan media yang materinya dapat diunduh dan dapat diakses oleh semua orang dengan menggunakan aplikasi tertentu. Siniar ini menjadi media audio digital yang berbeda dengan radio yang merupakan media analog (Klose \& Schreiber, 2017).

Siniar ini lebih dikenal dengan nama Podcast. Penggunaan kata Podcast berasal dari istilah iPod dan broadcasting. Pemutar musik ini dahulu dikelola oleh apple yang menghasilkan iPod tetapi lambat laun dikembangkan oleh android yang banyak dipakai oleh masyarakat untuk dinikmati.

Siniar dapat dipublikasikan melalui dalam jaringan sehingga dapat di download oleh siswa melalui komputaer, handphone ataupun laptop secara gratis maupun berbayar. Penyajian Siniar dan Very Easy Syndication dalam bentuk website dan portal. Pembaca yang mendukung file dengan audio. Versi 2.0 dari RSS dapat mengenali dan menafsirkan file audio seperti file MP3. RSS adalah sindikasi yang dapat digunakan pengguna untuk mengunduh konten terbaru dari situs web secara otomatis. Siniar ini dapat diakses dengan menggunakan spotify yang dikenal oleh semua masyarakat. 
Proses Penggunaan Siniar meliputi tahaptahap sebagai berikut; a) mempersiapkan peralatan yang dibutuhkan; b) melakukan analisis kompetensi dasar dan tujuan pembelajaran; b) menyusun skenario pembelajaran materi yang akan disampaikan; c) melakukan perekaman dengan menggunakan peralatan; d) melakukan editing; e) Review suara, f) mempublikasikan lewat aplikasi anchor dan evaluasi melalui aplikasi sportify dan achor.

Tahapan untuk melaksanakan penggunaan Siniar membuat rencana pembelajaran yang meliputi merumuskan indikator pembelajaran, merumuskan tujuan, menyusun materi pembelajaran, membuat skenario dan melakukan refleksi

\section{Pembahasan Inovasi yang dilakukan}

Inovasi yang dilakukan dalam best practise ini adalah penulis membuat sendiri untuk media pembelajarannya yang kemudian digunakan dalam menjelaskan pembelajaran sosiologi sesuai materi yang akan disampaikan. Siniar ini dalam pelajaran sosiologi masih belum dikenal oleh para pengajar padahal media pembelajaran ini merupakan solusi dalam pembelajaran jarak jauh yang sangat humanis di masa pandemi saat ini. Pembuatan Siniar yang dapat dilakukan oleh semua pengajar dan dapat dinikmati oleh semua siswa. Penggunaan Siniar menjadi inovasi yang dapat dikembangkan untuk mata pelajaran yang lain dan khususnya mata pelajaran sosiologi di masa pandemi saat ini.

Bentuk penelitian dengan strategi kualitatif deskriptif merupakan praktek terbaik untuk perencanaan ini. Penelitian deskripsi adalah suatu penelitian yang menggambarkan tentang fenomena yan alamiah ataupun buatan misalnya aktivitas, karakteristik, hubungan, kesamaan dan perbedaan. Fenomenan ini saling berkaitan yang digambarkan dalam penelitian ini. (Sukmadinata, 2006). Dalam penulisan ini merangkum pengalaman terbaik selama pandemi covid-19 dalam menyikapi permasalahan yang ada pada proses pembelajaran jarak jauh. Siswa kelas XII IPS2 SMAN 1 Bantul Semester 2 tahun pelajaran 2020/2021 menjadi subyek dan lokasi penelitian ini. 32 responden menjadi subjek penelitian. Pemilihan subjek dalam penelitian ini karena siswa mengikuti video conference meeting pada setiap pertemuan pembelajaran jarak jauh selama pandemi covid-19 di kelas sangat rendah. Data primer yang dikumpulkan oleh penyusun dengan menggunakan formulir google adalah data yang digunakan. Teknik pengumpulan data dilakukan dengan penyebaran angket terhadap jawaban pembelajaran yang dilakukan. Teknik analisis data yang digunakan dalam analisis ini menggunakan tahap pengumpulan data melalui Google form, mereduksi data yang ada di google form, menyajikan data dalam bentuk data kualitatif dan data kuantitatif, dan terakhir menarik kesimpulan.

Dalam penggunaan Siniar ini dilaksanakan untuk materi pemberdayaan masyarakat. Analisis ini dilakukan karena materi ini berisi materi secara konsep dan teori yang dapat menggunakan Siniar. Dalam penggunaan Siniar ini dilaksanakan selama 2 kali pembelajaran yaitu tanggal 20 Januari 2021 dan 27 Januari 2021.

Alasan pemilihan media pembelajaran sosiologi dengan menggunakan Siniar sebagai media pembelajaran adalah selama pembelajaran jarak jauh siswa mulai bosan untuk mengikuti pembelajaran, ketika menggunakan media tatap muka secara online hanya $70 \%$ yang mengikuti pembelajaran, peserta didik yang merasa kuotanya terkuras apabila menggunakan media tatap muka, kemampuan peserta didik yang heterogen secara finansial, ada siswa yang kadang tertinggal masuk dalam pembelajaran dengan berbagai alasan misalnya tertidur, diminta orang tuanya mengerjakan pekerjaan rumah, ataupun baru ada keperluan yang lain.

Mata pelajaran sosiologi yang terkesan monoton memacu peserta didik untuk malas mengikuti pembelajaran karena hanya menjelaskan materi yang bersifat teori. Motivasi siswa akan menjadi rendah dan keinginan untuk mengikuti pembelajaran semakin sedikit. Untuk itu perlu kombinasi, kreativitas dalam menggunakan media pembelajaran yang bervariasi.

Dari beberapa alasan tersebut maka dengan penggunaan Siniar sebagai media pembelajaran menjadi salah satu solusi seorang pendidik untuk dilaksanakan dalam pembelajaran jarak jauh ini dalam jaringan.

Siniar menjadi salah satu pembeajaran yang inovatif untuk merancang kegiatan pembelajaran dimasa pandemi, Siniar dapat membantu proses pembelajaran di dalam kelas dan luar kelas khususnya di masa pandemi, Siniar dapat meningkatkan pendidik dalam kesiapan dan mempersiapkan pembelajaran yang baik baik

Implementasi stategi pemecahan masalah dalam pembelajaran jarak jauh selama pandemi covid-19 untuk pembelajaran sosiologi dengan menggunakan Siniar adalah memberikan penugasan siswa untuk mengikuti pembelajaran melalui Siniar yang diberikan oleh gurunya.

Proses pembuatan Siniar meliputi tahaptahap: 
Tabel 1. Tahapan Operasional Pembuatan Siniar

\begin{tabular}{|c|c|c|}
\hline Tahapan & Kegiatan & Keterangan \\
\hline \multirow[t]{3}{*}{ 1. Perencanaan } & $\begin{array}{l}\text { a. Mempersiapkan } \\
\text { Peralatan yang } \\
\text { digunakan }\end{array}$ & $\begin{array}{l}\text { handphone atau gawai, microphone, patform anchor dan } \\
\text { patform sportify. }\end{array}$ \\
\hline & $\begin{array}{l}\text { b. Melakukan analisis } \\
\text { Kompetensi dasar } \\
\text { dan tujuan } \\
\text { pembelajaran }\end{array}$ & $\begin{array}{l}\text { Dalam penulisan ini mengambil materi tentang } \\
\text { pemberdayaan masyarakat dan kearifan lokal. Alasan } \\
\text { pemilihan ini karena dengan media Siniar ini guru dapat } \\
\text { menjelaskan secara langsung dengan audio nya tanpa } \\
\text { bertatap muka dengan video conference. }\end{array}$ \\
\hline & $\begin{array}{l}\text { c. Menyusun skenario } \\
\text { pembelajaran }\end{array}$ & $\begin{array}{l}\text { Mempersiapkan modul, diktat atau unit kegiatan belajar } \\
\text { mandiri (UKBM). }\end{array}$ \\
\hline \multirow[t]{4}{*}{ 2. Pelaksanaan } & $\begin{array}{l}\text { a. Melakukan } \\
\text { perekaman } \\
\text { b. Melakukan editing }\end{array}$ & $\begin{array}{l}\text { Proses perekaman ini dilaksanakan dalam ruang yang senyap } \\
\text { agar proses perekaman berjalan dengan baik. } \\
\text { untuk memberikan efek dalam proses nya dengan } \\
\text { memberikan selingan musik ataupun pesan yang lain. }\end{array}$ \\
\hline & $\begin{array}{l}\text { c. Melakukan review } \\
\text { suara }\end{array}$ & 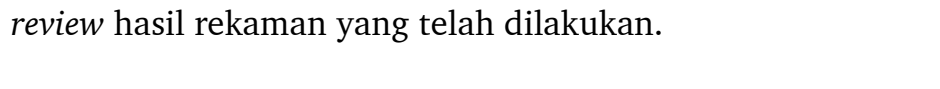 \\
\hline & $\begin{array}{l}\text { d. Melakukan } \\
\text { publikasi dengan }\end{array}$ & $\begin{array}{l}\text { Hasil rekaman yang dihasilkan oleh guru dipublikasikan atau } \\
\text { di upload dalam platfom Achor. }\end{array}$ \\
\hline & $\begin{array}{l}\text { menggunakan } \\
\text { aplikasi Anchor }\end{array}$ & $\begin{array}{l}\text { Adapun untuk Siniar yang dibuat oleh penulis dalam Siniar } \\
\text { "Merdeka Belajar Sosiologi SMAN } 1 \text { Bantul". Podcsat ini dapat } \\
\text { dinikmati dengan menggunakan sportify. }\end{array}$ \\
\hline 3. Evaluasi & Evaluasi & $\begin{array}{l}\text { Untuk melakukan evaluasi dapat dilakukan dengan } \\
\text { menggunakan platfom Anchor dan sportify. }\end{array}$ \\
\hline
\end{tabular}

Setelah tahapan pembuatan Siniar yang akan digunakan maka langkah selanjutnya adalah melaksankan pembelajaran secara daring.
Tahapan yang dilakukan oleh penulis adalah menyusun Rencana Pelaksanaan Pembelajaran sebagai berikut:

Tabel 2. Kegiatan Tahap Rencana Pelaksanaan Pembelajaran

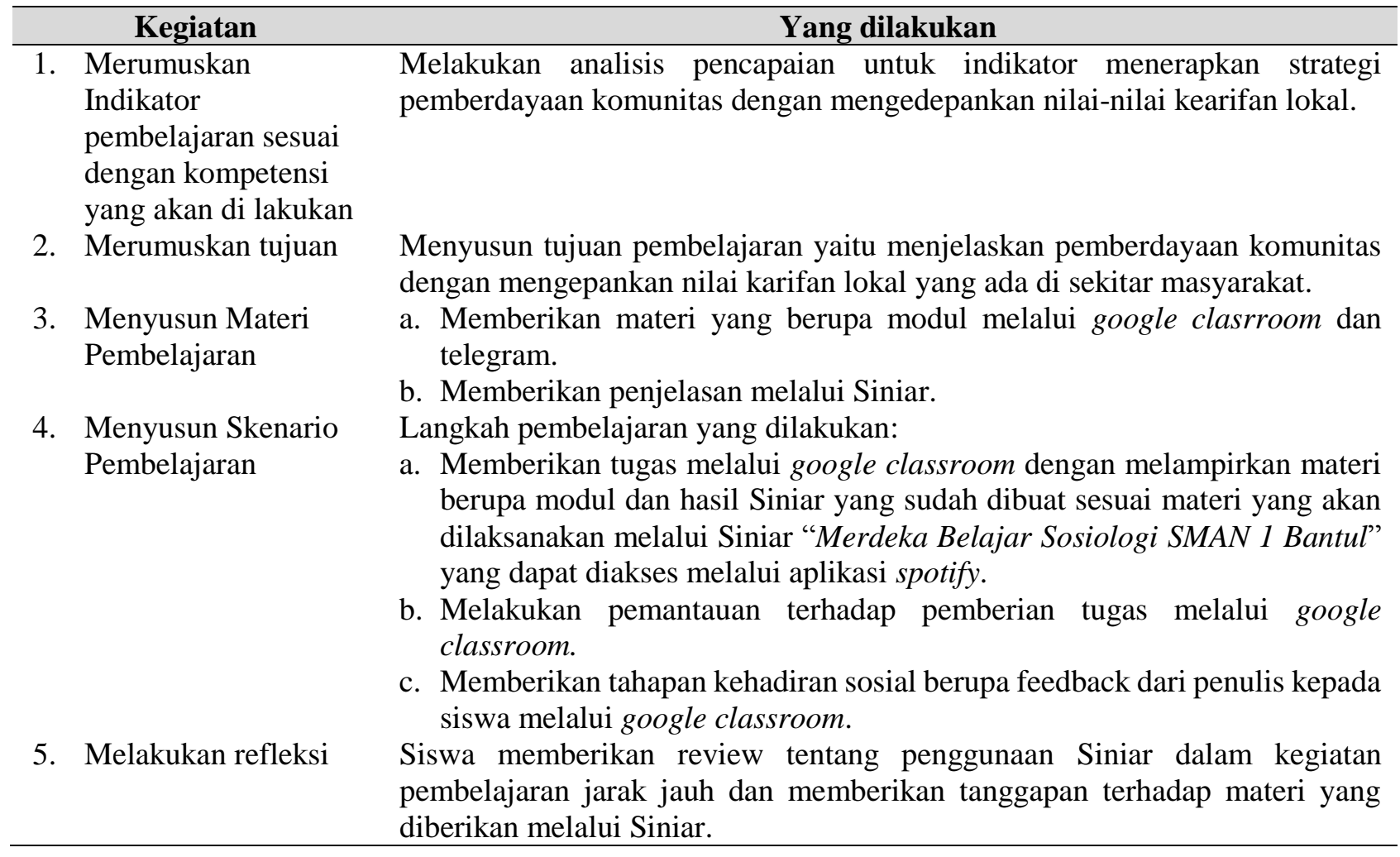




\section{Hasil yang dicapai}

Dalam penulisan best pratice ini penulis mendapatkan bebarapa hasil yang dicapai. Hasil yang dicapai dengan penggunaan Siniar dalam mata pelajaran sosiologi di masa pandemi di dapat oleh penulis melalui google form yang diitanggapi oleh siswa sebagai respondennya. Tanggapan dari siswa ada keterikatan (minat) dan semangat siswa dalam melanjutkan proses pembelajaran melalui media Siniar. Untuk menilai keterikatan dan semangat belajar siswa dengan menggunakan angket yang mendapat jawaban dari siswa sebagai berikut:

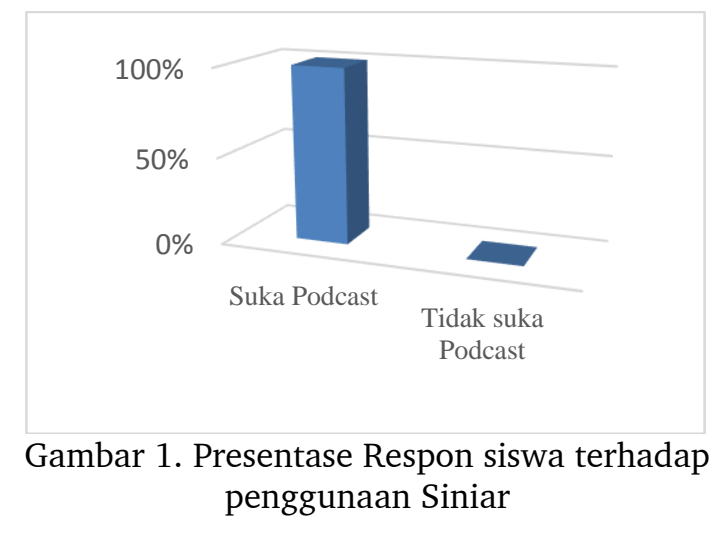

Dalam gambar 1 di atas menunjukkan bahwa hasil tanggapan siswa yang dibagikan melalui google form diperoleh kesimpulan bahwa $100 \%$ responden menyukai Siniar dalam pembelajaran dan tidak ada responden yang menyatakan tidak suka.

Indikator pemahaman materi yang diberikan dapat diserap oleh siswa yang diberikan melalui Siniar dapat diserap oleh siswa. Hal ini terbuti dari hasil tanggapan siswa melalui google form yang diberikan kepada siswa sebagai berikut:

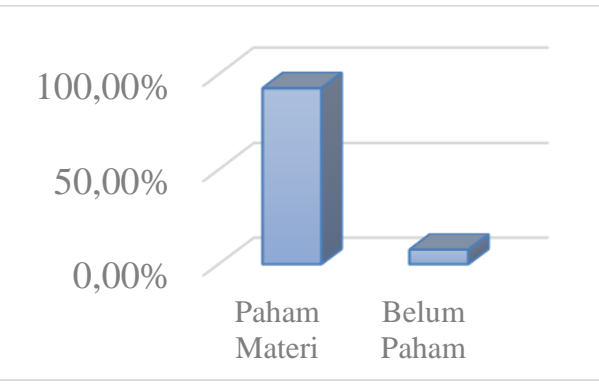

Gambar 2. Persentase Respon siswa terhadap Pemahaman materi yang diberikan melalui penggunaan Siniar

Berdasarkan tanggapan siswa, 92,3 persen responden menyatakan memahami materi yang disampaikan oleh guru. Ada sekitar 7,7 persen yang menyatakan tidak paham materi. Dapat disimpulkan bahwa masih ada sekitar 7,7 persen yang perlu direfleksikan dalam penggunaan Siniar ini, misalnya dengan menyempurnakan kreasinya.

Dalam pemilihan pemedia pembelajaran harus mempertimbangkan kemudahan dan ketersedian media pembelajaran. Berdasarkan tanggapan siswa didapat hasil sebagai berikut:

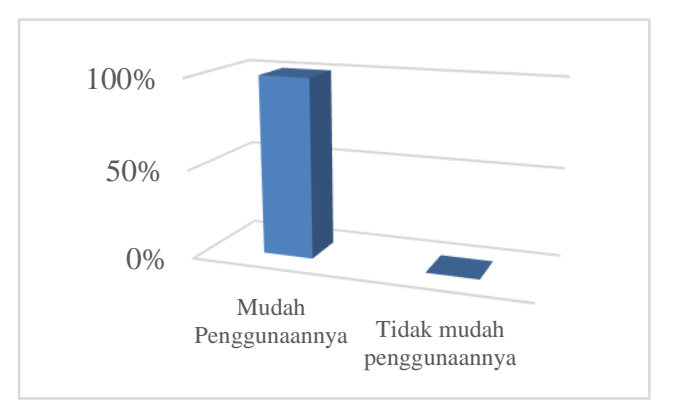

Gambar 3: Persentase Respon siswa terhadap kemudahan dan ketersediaan penggunaan Siniar

Siswa juga mudah mengoperasikan media pembelajaran dengan menggunakan Siniar dari tabel diagram. Data yang diperoleh 100 persen menyatakan bahwa dalam pembelajaran jarak jauh menggunakan Siniar ini mudah dan tidak ada responden yang mengatakan bahwa menggunakan media Siniar ini sulit.

Selain itu data yang lain didapat dengan google form dengan tanggapan siswa dengan angket terbuka. Tanggapan siswa terhadap penggunaan Siniar ini sebagai berikut: 1) siswa secara psikologis tidak merasa terbebani dengan penggunaan kuota yang menguras banyak dibandingkan dengan menggunakan platform tatap layar; 2) semua siswa dapat mengakses kapanpun, dimanapun. Siswa dapat mendownload Siniar sesuai dengan waktu yang mereka punyai; 3) rendahnya biaya penggunaan Siniar dibandingan dengan platform yang lain; 4) materi yang telah disampaikan akan tersimpan dalam platform achor dan spotify sehingga tidak membebani memori handphone dan laptop; 4) bagi siswa juga merasa senang karena dapat dilakukan dengan aktifitas yang lain; 5) Penjelasan dalam Siniar dan pendampingan modul/ diktat yang diberikan sangat membantu siswa dalam belajar

Bagi penulis ada hasil yang didapat bahwa dengan peranan Siniar dalam pembelajaran daring selama masa pandemi dalam mata pelajaran sosiologi sebagai berikut: 1) kuota yang digunakan sangat irit. Untuk menjelaskan materi selama 9 menit 13 detik hanya membutuhkan kuota sebanyak 13,27 megabyte; 2) pendidik kini siap melakukannya dengan efisien, nyaman, dan dapat dilakukan dimana saja (fleksibel). Hal ini 
berbeda dengan penggunaan video pembelajaran yang membutuhkan waktu yang lama dalam membuatnya. Dengan penggunaan Siniar, seorang pendidik hanya membutuhkan waktu sekitar 30 menit untuk mempersiapkannya; 3) hasil publikasi berupa Siniar dapat dinikmati oleh sekolah lain karena siswa saat ini sudah dekat dengan penggunaan Siniar; 4) meningkatkan kemampuan publik speaking bagi pendidik dalam menyampaikan materi dalam Siniar. Dengan penggunaan Siniar materi harus terencana dengan baik dan terarah serta menarik. 5) Tidak dapat digunakan untuk memberikan materi yang bersifat menjelaskan detail sehingga guru harus mempersiapkan modul/ diktat terlebih dahulu sebelum Siniar dibagikan oleh siswa.

Hasil penelitian ini sesuai dengan yang disampaikan oleh Faiza dkk yang menyimpulkan bahwa peranan Siniar dapat melampaui batas ruang dan waktu. Dibandingkan media audio lain, nilai terobosan Siniar ini adalah dapat diunduh dan disimpan di laptop dan perangkat seluler. Keunggulannya bisa digunakan di mana saja dan kapan saja untuk memastikan Siniar sangat sukses dan andal. Dengan demikian, siswa dapat melakukan hal-hal lain, seperti berbaring, memasak, atau mengemudi. (Faiza Indriastuti \& Wawan Tri Saksono TEst, 2014)

Hasil penelitian peranan siniar yang menunjukkan bahwa materi dapat dipahami oleh siswa dengan baik diperkuat oleh penelitian oleh Ratna Dwi yang mengemukakan hasil penelitiannya bahwa penggunaan Siniar juga dapat digunakan oleh siswa untuk memahami prinsip, ide dalam implementasi pembelajaran jarak jauh.(Ratna Dwi Susilowati,Sutama Sutama, Nuqhty Faiziyah, 2020).

Peranan Siniar dalam mata pelajaran sosiologi ini dapat meningkatkan motivasi belajar siswa. Hal ini sesuai dengan penelitian yang disampaikan dalam jurnal yang menyampaikan bahwa Siniar ini juga bisa diperluas ke topik sejarah dalam ilmu sosial yang berhasil meningkatkan pembelajaran sebesar 45,9 persen dan dengan menggunakan media audio berbasis Siniar pada konten Sriwijaya dalam kategori yang tinggi. (Adhitya Rol Asmi, Aulia Novemy Dhita, Supriyanto, 2019)

\section{Kendala-kendala yang ditemukan}

Selama pandemi covid-19, beberapa tantangan yang dihadapi saat menggunakan Siniar dalam pembelajaran sosiologi adalah;1) minimnya interaksi antara guru dan siswa secara langsung. Siswa dalam mendengarkan Siniar tidak dapat bertanya secara langsung dengan gurunya. Karena hanya bersifat satu arah. Hal ini menjadi pekerjaan tersendiri untuk memadukan dengan platfom yang lain misalnya dengan menggunakan media sosial whatapps, telegram; 2) kurangnya penguasaan ketrampilan dalam mengoperasian perekaman suara. Keterampilan pendidik untuk mengoperasionalkan perekaman dan melakukan editing yang perlu ditingkatkan agar lebih menarik di dalam Siniarnya; 3) keterampilan public speaking bagi pendidik untuk melakukan perekaman. Keterampilan pendidik yang sering kali menjelaskan matei sampai melebar dari skenario juga menjadi kendala. Sehingga keterampilan public speaking perlu ditingkatkan.

\section{Faktor-faktor pendukung}

Penggunaan Siniar dalam mata pelajaran sosiologi dalam masa pandemi covid-19 mempunyai beberapa faktor pendukung. Adapun faktor pendukung tersebut; 1) setiap pendidik dan peserta didik hampir semuanya memunyai ganget/ handphone versi android yang dapat mengakses Siniar, 2) peserta didik yang sudah mengenal platfom spotify untuk mendengarkan materi yang disampaikan dalam Siniar; 3) penggunaan Siniar yang dapat diakses dimana dan kapanpun oleh peserta didik,; 4) fasilitas dalam gawai yang sudah tersedia alat perekamnya dapat digunakan untuk pembuatannya; 5) jaringan internet yang sudah disetiap daerah. Apabila ada yang tidak ada jaringan maka peserta didik masih dapat mengakses pada waktu ada dalam jaringan; 6) minat dan komitmen siswa yang tinggi unuk mengikuti pembelajaran di SMAN 1 Bantul; 7) komunikasi yang insentif antara guru dan siswa terhadap materi pembelajaran yang disampaikan; 8) fasilitas studio rekaman yang mendukung pembuatan Siniar di SMAN 1 Bantul; 9) setiap guru sudah mempunyai modul/ diktat yang dapat menjadi pegangan siswa belajar dirumah; 10) Kepala sekolah berkomitmen kuat pada meningkatkan kemampuan untuk guru. Kepala sekolah memberi guru kemampuan untuk berinovasi dalam pembelajaran online, selalu memberikan semangat, dukungan dan fasilitas yang dibutuhkan guru; 11) peran serta komitmen sekolah dalam pendanaan pengembangan sekolah memberikan fasilitas yang dibutuhkan oleh guru; 12) Pengawas sekolah memberikan dukungan, bimbingan dan motivasi belajar untuk meningkatkan pembelajaran.

\section{Alternatif pengembangan}

Tidak lanjut pengembangan penggunaan Siniar dalam mata pelajaran sosiologi di masa pandemi covid-19 sebagai berikut: 1) penerapan pada materi dan mata pelajaran yang lain. Siniar ini dapat diunakan dalam semua mata pelajaran 
yang membutuhkan penjelasan kepada siswa lebih detail contohnya mata pelajaran bahasa indonesia, bahasa inggis dalam kemampuan menyimak; 2) memadukan Siniar dengan video Siniar untuk meminimalisir kekurangan media Siniar ini; 3) pemberian peningkatan kompetensi guru dalam broardcast dalam bentuk pelatihan secara langsung; 4) dukungan sekolah yang lebih optimal untuk pembelian peralatan yang mencukupi untuk pembuatan Siniar.

\section{Simpulan dan Saran}

Penggunaan Siniar sebagai media pembelajaran jarak jauh untuk mata pelajaran sosiologi secara di masa pandemi di kelas XII IPS 1 semester 2 Tahun Pelajaran 2020/2021 mempunyai dampak yaitu: a) dapat meningkatnya minat dan motivasi belajar siswa dalam mengikuti proses pembelajaran; b) siswa secara psikologis tidak merasa terbebani; c) irit dalam penggunaan Siniar; d) semua siswa dapat mengakses kapanpun, dimanapun; e) rendahnya biaya penggunaan Siniar; f) pendidik juga dalam mempersiapkan dapat dilakukan dengan mudah, cepat dan dapat dilakukan dimana aja; f)hasil publikasi berupa Siniar dapat dinikmati oleh siapa saja; g) materi yang telah disampaikan akan tersimpan dalam platform achor dan spotify sehingga tidak membebani memori handphone dan laptop; h) meningkatkan kemampuan publik speaking bagi pendidik dalam menyampaikan materi dalam Siniar. Penggunaan Siniar materi dapat terencana dengan baik dan terarah serta menarik. Hasil penelitian menyimpulkan bahwa sebanyak $100 \%$ responden menyatakan menyukai penggunaan Siniar, 92,3\% responden menyatakan paham terhadap materi yang digunakan dan $100 \%$ responden menyatakan mudah dalam penggunaan Siniar sebagai media pembelajaran. Selain itu bahwa penggunaan Siniar dapat meningkatnya minat dan motivasi belajar siswa dalam mengikuti proses pembelajaran selama masa pandemi. Penggunaan Siniar ini sebagai salah satu solusi dalam pembelajaran jarak jauh di masa pandemi covid-19.

Saran yang diberikan berdasarkan penggunaan Siniar dalam mata pelajaran sosiologi dalam pembelajaran jarak jauh di masa pandemi antara lain; 1) perekaman suara yang dimaksimalkan agar lebih jernih agar siswa dapat mendengarkan materinya lebih maksimal karena inti dalam siniar adalah ada di audio-nya; 2) selingan musik berupa lagu-lagu yang millenial dapat disisipkan dalam rekaman suaranya agar siswa lebih enjoy dalam mendengarkan materinya; 3) Media Siniar dapat digunakan oleh pihak sekolah dalam melakukan sosialisasi program sekolah kepada masyarakat secara luas. 4) durasi waktu yang dibatasi tidak lebih 15 menit agar siswa tidak bosan untuk mendengarkan siniar ini.

\section{Daftar Pustaka}

Adhitya Rol Asmi, aulia Novemy Dhita, Supriyanto. (2019). Pengembangan audio Podcast pada Materi Sejarah Lokal di Sumatera Selatan. Jurnal Historia Pendidikan dan Penelitian Sejarah http://dx.doi.org/10.17509/historia.V3iI.2 $\underline{017}$

Brings, L. J. (1977). Intructional Design Education Technology Publications..New Jersey: Englewood Cliffs

Faiza Indriastuti \& Wawan Tri Laksono Test. (2014). Podcast Sebagai Sumber Belajar Berbasis Audio. Jurnal Teknologi Pendidikan. Volume 18 No 3

Handoko, M (2002). Motivasi Daya Penggerak Tingkah Laku. Yogyakarta: Kanisius

Komppelman, H. (2013). Using Podcast In Distance Education. In Proceeding of Internasional Conference e-learning, (hal 303-310).

Kosasih, Robertus Angkowo \& A. (2007). Optimalisasi Media Pembelajaran. Jakarta: PT Grasindo

P.James, Mark Bullen \& Diane. (2007). Making The Transition E-Learning: Stategies and Issues. Canada: Information Science Pub

Ratna Dwi Susilowati, Sutama Sutama, Nuqhty Faiziyah. (2020). Penerapan Podcast pada Aplikasi Sportyfy sebagai media pembelajaran matematika di tengah pandemi covid-19. Jurnal Riset dan inovasi matematika, 4(1) http://dx.doi.org/10.26740/jrpipm.v4n1.p 68-78

Klose, Rebecca \& Schreiber, Christof. (2017). Matematical Audio-Podcast For Theacher Education and School. Teacher and Curriculum, ISSN 2382-0349, 17(2) 41-46. http://dx.doi.org/10.15663/tandc.v17i2.161

Scramm, W. (1977). Big Media Little Media. London: Sega Publik-Baverly Hills

Sharon E Smaldino, Deborah L. Lowther dan James D Russell. (2014). Intructional Technology and Media For Learning. Jakarta: Kencana

Sukmadinata. (2006). Penelitian Kualitatif. Bandung: Graha Aksara.

UNICEF. (2020). The Remote Learning Reachability. New York, AS: https://www.unicef.org. 